\title{
Overview of Kizildere Geothermal Power Plant in Turkey
}

\author{
Gulden Gokcen ${ }^{\mathrm{a}}$, Harun Kemal Ozturk ${ }^{\mathrm{b}}$, Arif Hepbasli ${ }^{\mathrm{c}, *}$ \\ ${ }^{a}$ Department of Mechanical Engineering, Izmir Institute of Technology, 35437 Gulbahce Koyu, Urla, Izmir 35430, Turkey \\ ${ }^{\mathrm{b}}$ Department of Mechanical Engineering, Faculty of Engineering, Pamukkale University, 20017 Camlik, Denizli, Turkey \\ ${ }^{\mathrm{c}}$ Department of Mechanical Engineering, Faculty of Engineering, Ege University, 35100 Bornova, Izmir, Turkey
}

Received 7 December 2002; accepted 24 May 2003

\begin{abstract}
Achieving sustainable development is a target that is now widely seen as important in worldwide public opinion. In this context, the utilization of renewable energy resources such as solar, geothermal and wind energy appears to be one of the most efficient and effective ways of achieving this target. Recently, power generation from geothermal energy has become of big importance in Turkey, which is located on the Mediterranean sector of the Alpine-Himalayan Tectonic Belt and is among the first seven countries in abundance of geothermal resources around the world. The main objective in doing the present study is twofold, namely: (a) to investigate Turkey's geothermal energy potential for power generation and (b) to overview the Denizli-Kizildere geothermal power plant (DKGPP) with an installed capacity of $20.4 \mathrm{MW}_{\mathrm{e}}$, which is at present the only operating geothermal power plant of Turkey. Based on the drilling data, which have been gathered to date, Turkey's geothermal energy potential for power generation is determined to be 764.81 $\mathrm{MW}_{\mathrm{e}}$. Electricity generation projections of Turkey are also $500 \mathrm{MW}_{\mathrm{e}}$ from Germencik, Kizildere, Tuzla and several of the other fields by the year 2010 and $1000 \mathrm{MW}_{\mathrm{e}}$ by 2020. The Denizli-Kizildere geothermal field has an estimated capacity of $200 \mathrm{MW}_{\mathrm{e}}$. The DKGPP was put into operation in 1984 and has been operated since then. It produced an electrical energy of 89,597 MWh in 2001, representing an electric power of 10.6 $\mathrm{MW}_{\mathrm{e}}$ in the same year. Present applications have shown that in Turkey, geothermal energy is a promising alternative and can make a significant contribution towards reducing the emission of greenhouse gases. As the public recognizes the projects, the progress will continue.
\end{abstract}

(C) 2003 Elsevier Ltd. All rights reserved.

Keywords: Electricity generation; Geothermal energy; Geothermal fields; Power generation; Power plant; Renewable energy; Kizildere; Turkey

\footnotetext{
${ }^{*}$ Corresponding author. Tel.: +90-232-388-8562/4000/1897; fax: +90-232-388-0378/8562.

E-mail addresses: hepbasli@bornova.ege.edu.tr, hepbasli@egenet.com.tr (A. Hepbasli).
} 


\section{Introduction}

Despite the limitations of Planet Earth's conventional energy resources, the demand for energy is continuously rising as a result of increasing population and industrialization. The utilization of fossil energy resources is presently causing increasingly disastrous effects on the global environment. In this regard, there is urgent need to deploy sustainable and environmentally clean energy sources. An important contribution could be made by rapidly expanding the use of renewable energy sources, such as geothermal energy [1].

Geothermal energy is the energy contained as heat (the thermal energy) within the Earth's interior. The origin of this heat is linked to the internal structure of our planet and the physical processes occurring there. Geothermal energy, is to some extent, a renewable energy source, since a geothermal resource usually has a projected life of 30-50 years. The life of a resource may be prolonged by a reinjection process, which may compensate for at least part of the fluid extracted by production [2-4].

Table 1 illustrates installed geothermal generating capacities in the top 10 countries and Turkey between 1995 and 2000. Huttrer [5,6] has reviewed the world wide application of geothermal energy for power generation and reported the following: (a) geothermally fueled electric power is being generated in 21 nations as of February 2000, (b) the installed capacity has reached 7974 $\mathrm{MW}_{\mathrm{e}}$ in 2000, which is a $16.7 \%$ increase since 1995, (c) the total energy generated during the last 5 years has been at least 49,261 GWh, (d) about 1165 wells more than $100 \mathrm{~m}$ deep have been drilled. Huttrer [6] also concluded that greater increases in the total international installed geothermal power generation capacity were inhibited by the economic crisis that occurred in southeast Asia, by the low petroleum prices that prevailed during the 5 year period from 1995 to 2000 and by serious capacity declines at The Geysers field in California, USA.

The share of the top three countries, namely the US, The Philippines and Italy, in total installed capacity of $7974 \mathrm{MW}_{\mathrm{e}}$ in 2000 (with the generation of 49.3 billion $\mathrm{kWh}$ in the same year) was about 27.94\%, 23.94\% and 9.8\%, respectively, followed by Mexico at 9.47\%, Indonesia at 7.39\%,

Table 1

Installed geothermal generating capacities in the top 10 countries and Turkey between 1995 and 2000 [5,6]

\begin{tabular}{llllll}
\hline Country & $1995\left(\mathrm{MW}_{\mathrm{e}}\right)$ & $2000\left(\mathrm{MW}_{\mathrm{e}}\right)$ & $2005\left(\right.$ estimated $\left.\mathrm{MW}_{\mathrm{e}}\right)$ & $1995-2000\left(\mathrm{MW}_{\mathrm{e}}\right.$ increase $)$ & \% Increase \\
\hline USA & 2816.7 & 2228 & 2376 & -588 & $\mathrm{n} / \mathrm{a}$ \\
Philippines & 1227 & 1909 & 2673 & 682 & 55.8 \\
Italy & 631.7 & 785 & 946 & 153.3 & 24.3 \\
Mexico & 753 & 755 & 1080 & 2 & 0.3 \\
Indonesia & 309.75 & 589.5 & 1987.5 & 279.75 & 90.3 \\
Japan & 13.705 & 549.6 & 566.9 & 133.195 & 32.2 \\
New Zealand & 286 & 437 & 437 & 151 & 52.8 \\
Iceland & 50 & 170 & 186 & 120 & 240 \\
El Salvador & 105 & 161 & 200 & 56 & 53.3 \\
China & 28.78 & 9.17 & $\mathrm{n} / \mathrm{a}$ & 0.39 & 1.35 \\
Turkey & 20.4 & 20.4 & 250 & 0 & 0 \\
Total $^{\mathrm{a}}$ & 6833 & 7974 & 11,414 & 1141 & 17 \\
\hline
\end{tabular}

\footnotetext{
${ }^{\text {a }}$ This total includes 22 countries, while in Argentina there were no installed capacities in 2000.
} 
Japan at $6.85 \%$, New Zealand at $5.48 \%$ and others at $9.13 \%$. By comparison, Turkey accounted for about $0.256 \%$ of the total [4-6].

Geothermal energy utilization may be divided into two categories, namely electric energy production and direct uses. Direct or non-electric utilization of geothermal energy refers to the immediate use of the heat energy rather than to its conversion to some other form, such as electrical energy. The geothermal energy source that can be easily converted into electrical power is generally considered renewable, because reservoirs may be recharged by rain and by reinjection of the spent water. In general, the geothermal fluid temperatures required for direct heat use are lower than those for economic electric power generation [7,8]. In this context, the main uses of geothermal energy in Turkey are: space heating and domestic water supply, greenhouse heating, balneology, $\mathrm{CO}_{2}$ and dry ice production process, heat pumps and electricity generation.

Turkey has a place among the first seven countries in abundance of geothermal resources around the world $[9,10]$. To date, wells were drilled in 105 geothermal fields although there are 170 geothermal fields in Turkey. The General Directorate of Mineral Research and Exploitation (MTA) has conducted geothermal energy explorations in Turkey. The inventorial works and chemical analyses of the hot springs and mineral waters started in $1962[11,12]$. The existence of more than 600 hot springs indicates that Turkey has an important geothermal energy potential, as given in detail elsewhere [13]. The data accumulated since 1962 show that the estimated direct use potential is about $31,500 \mathrm{MW}$, of which $10 \%$ is apparent. However, only $2-3 \%$ of this potential has so far been utilized [13-15].

\section{Turkey's geothermal energy potential for power generation}

About $95 \%$ of the 170 geothermal fields in Turkey are low-medium enthalpy fields, which are suitable for direct use applications. Among the remaining 9 fields, Denizli-Kizildere $\left(200-242{ }^{\circ} \mathrm{C}\right)$, Aydin-Germencik $\left(232^{\circ} \mathrm{C}\right)$, Canakkale-Tuzla $\left(174{ }^{\circ} \mathrm{C}\right)$, Aydin-Salavatli $\left(171^{\circ} \mathrm{C}\right)$, Kutahya-Simav $\left(162{ }^{\circ} \mathrm{C}\right)$, Manisa-Salihli $\left(150^{\circ} \mathrm{C}\right)$ and Izmir-Seferihisar $\left(153^{\circ} \mathrm{C}\right)$ are high enthalpy fields, which are suitable for electrical energy production $[12,13]$. The locations of the nine geothermal fields are illustrated in Fig. 1, while the four fields of highest temperature are summarized below.

The only operating geothermal power plant of Turkey is the Denizli-Kizildere geothermal power plant (DKGPP) located near Denizli City in Western Anatolia with an installed capacity of $20.4 \mathrm{MW}_{\mathrm{e}}$. The total capacity of the field is estimated to be $200 \mathrm{MW}_{\mathrm{e}}$, as given in Table 2 .

The exploration stage is completed in the Aydin-Germencik field, which is located to the west of Kizildere. Nine wells have been drilled into a $216-232{ }^{\circ} \mathrm{C}$ reservoir within marbles and quartzites at depths ranging from 285 to $1500 \mathrm{~m}$. The field capacity is estimated to be $100 \mathrm{MW}_{\mathrm{e}}$. The first stage of the field development is planned to build a $25 \mathrm{MW}_{\mathrm{e}}$ single flash plus binary power plant [16].

The third field with power generation potential is the Canakkale-Tuzla field in northwest Anatolia. The first well was drilled in 1982 . The temperature encountered was $174{ }^{\circ} \mathrm{C}$ in a reservoir at a depth of 333-553 m in volcanic rocks. A second well was drilled to $1020 \mathrm{~m}$. Temperatures up to $174{ }^{\circ} \mathrm{C}$ were recorded, but the permeability was low. Another two shallow wells (81 and $128 \mathrm{~m}$ ) also produced fluid at 146 and $165^{\circ} \mathrm{C}$. 


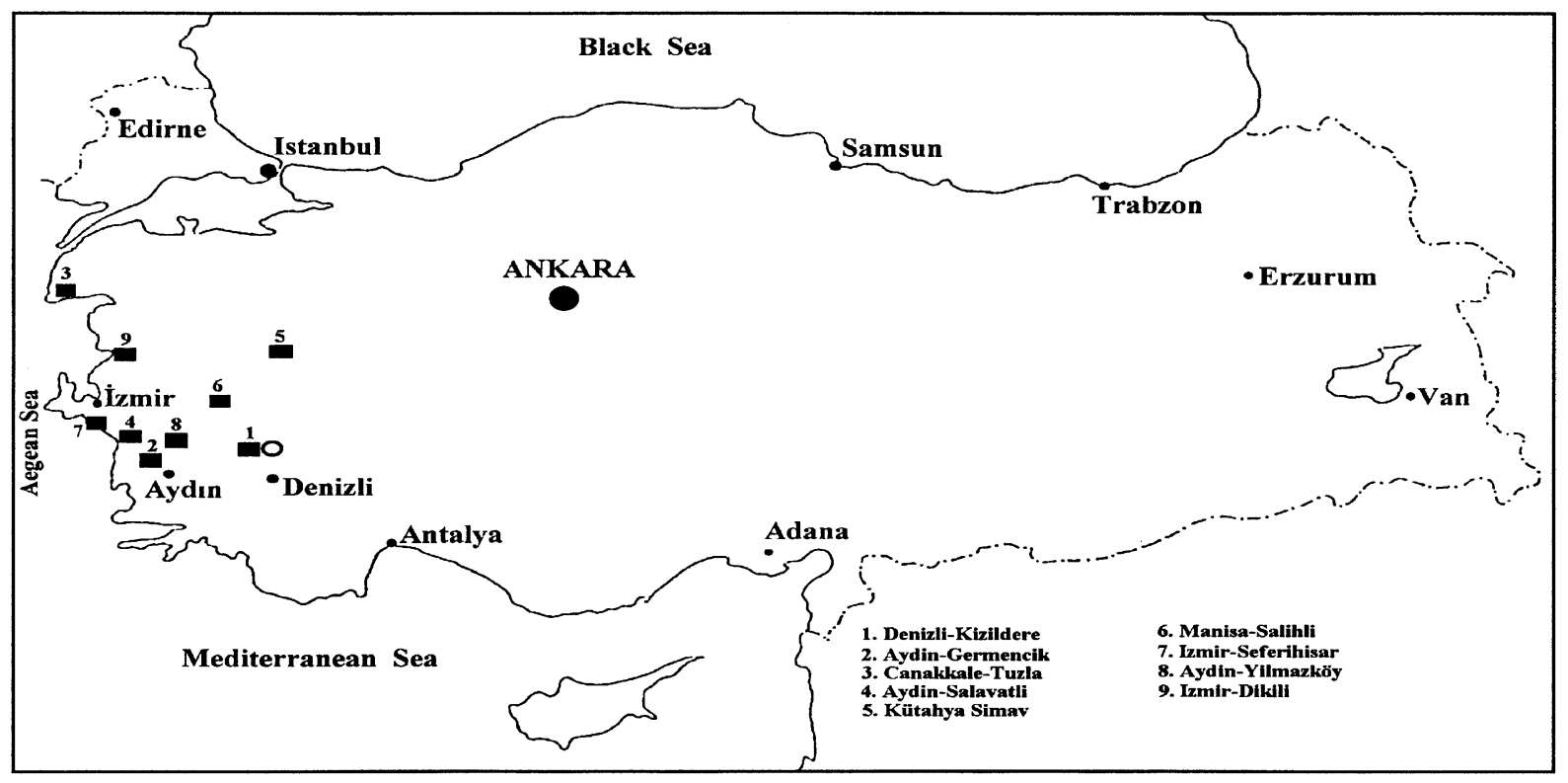

Fig. 1. Map indicating Turkey's geothermal fields suitable for power generation (o): the location of Turkey's only operating geothermal power plant (GPP): Denizli-Kizildere GPP.

Table 2

Utilization of geothermal energy for electricity generation in Turkey

\begin{tabular}{|c|c|c|c|c|c|c|c|}
\hline \multicolumn{8}{|c|}{ Unit rating } \\
\hline $\begin{array}{l}\text { Name of geother- } \\
\text { mal power plant }\end{array}$ & $\begin{array}{l}\text { Year com- } \\
\text { missioned }\end{array}$ & Status & $\begin{array}{l}\text { Type of } \\
\text { unit }\end{array}$ & $\begin{array}{l}\text { Potential } \\
\left(\mathrm{MW}_{\mathrm{e}}\right)\end{array}$ & $\begin{array}{l}\text { Operational } \\
\left(\mathrm{MW}_{\mathrm{e}}\right)\end{array}$ & $\begin{array}{l}\text { Under } \\
\text { construction or } \\
\text { planned }\left(\mathrm{MW}_{\mathrm{e}}\right)\end{array}$ & $\begin{array}{l}\text { Annual } \\
\text { production in } \\
2001(\mathrm{GWh} / \mathrm{yr})\end{array}$ \\
\hline Denizli-Kizildere & 1984 & $\mathrm{O}$ & $\mathrm{SF}+\mathrm{C}$ & 200 & 20.4 & - & 89.6 \\
\hline Aydin-Germencik & - & $\mathrm{P}$ & $\mathrm{SF}+\mathrm{B}$ & 100 & & 25 & - \\
\hline Aydin-Salavatli & - & $\mathrm{P}$ & $\mathrm{B}$ or $\mathrm{K}$ & N/A & & 5 & - \\
\hline
\end{tabular}

SF, single flash; C, condensing; B, binary; K, kalina; O, operational; P, planned; UC, under construction; N/A, no data.

The Aydin-Salavatli field has a reservoir temperature of $171^{\circ} \mathrm{C}$. It was planned to build a 5 $\mathrm{MW}_{\mathrm{e}}$ binary or Kalina cycle plant in the field, but this has not been realized yet [15].

Some attempts have been made towards installation of geothermal power plants in the fields of Aydin-Germencik-Omerbeyli, Canakkale-Tuzla and Manisa-Salihli-Caferbey. Besides this, there are also some investment attempts for electricity generation in Aydin-Salavatli by applying the autoproduction model [12], which is defined as the production of electricity by industrial facilities for their own use in Turkey based on the Turkish Trade Law [17].

The number of wells in the two geothermal fields, Denizli-Kizildere and Aydin-Germencik, is relatively more than that of the remaining fields. Besides this, the geothermal wells drilled are insufficient in the other 7 geothermal fields. Therefore, studies on the determination of the potential of these fields are still in progress $[12,16]$. Based on the drilling data, which have been 
gathered to date, Turkey's geothermal energy potential for power generation is determined to be 764.81 $\mathrm{MW}_{\mathrm{e}}$ [12]. Electricity generation projections of Turkey are also $500 \mathrm{MW}_{\mathrm{e}}$ from Germencik, Kizildere, Tuzla and several of the other fields by the year 2010 and $1000 \mathrm{MW}_{\mathrm{e}}$ by 2020 [5].

\section{Brief historical development of the Denizli-Kizildere geothermal power plant}

The Denizli-Kizildere geothermal field (DKGF) is located $30 \mathrm{~km}$ away from the province of Denizli, Western Anatolia, Turkey, as can be seen in Fig. 2. This field is the first and only geothermal field developed in Turkey. The first geological, geochemical, and geophysical studies were conducted with the support of the United Nations Development Program (UNDP) in 1966. Two stratigraphically separate zones in the field were initially identified as first and second reservoirs during the exploration stage. The shallow reservoir has a temperature of $190-200{ }^{\circ} \mathrm{C}$, a depth of up to $706 \mathrm{~m}$, a steam fraction of $10 \%$ and moderate permeability. The deeper one has $200-212{ }^{\circ} \mathrm{C}$

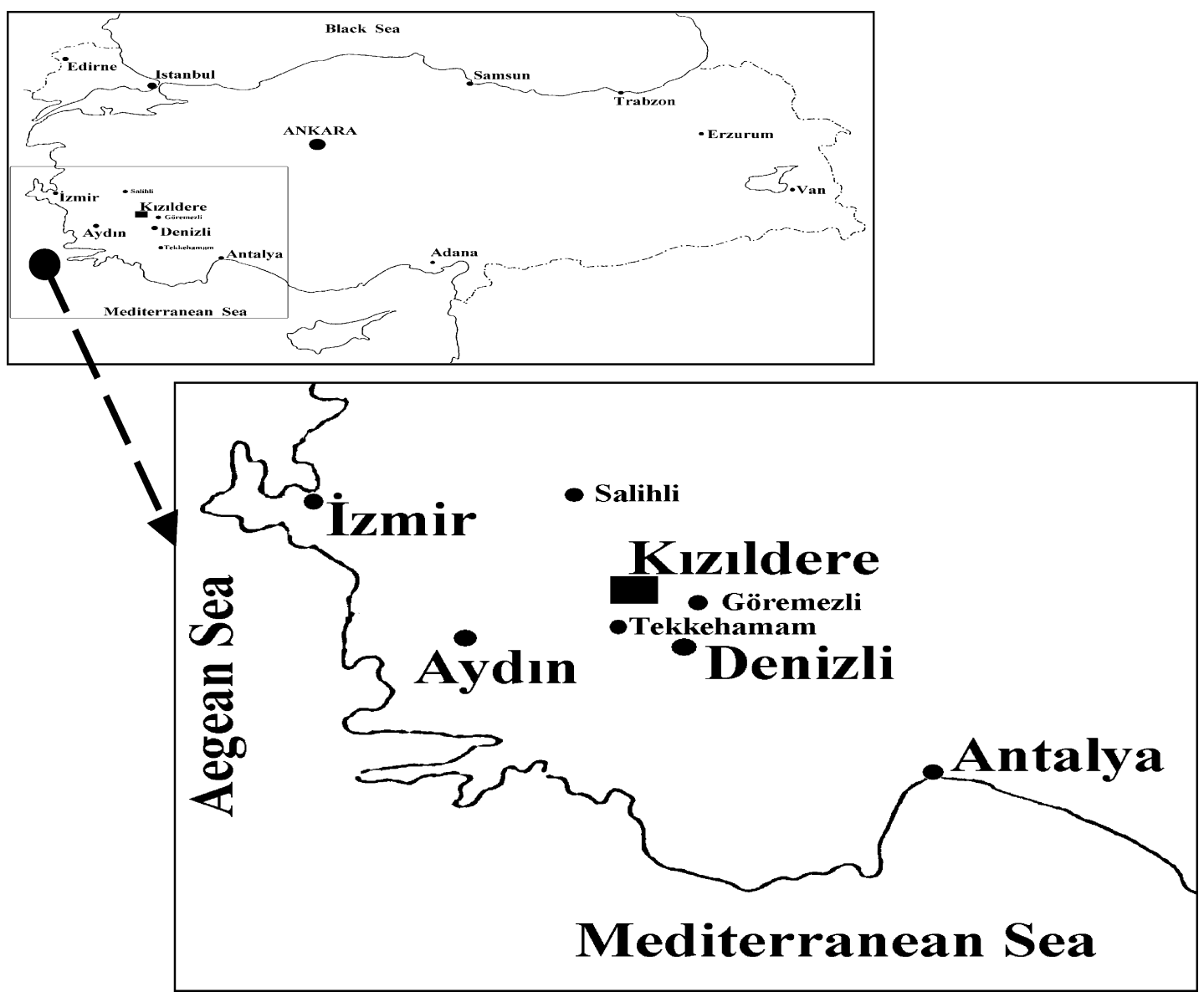

Fig. 2. Location of the Denizli-Kizildere geothermal field. 


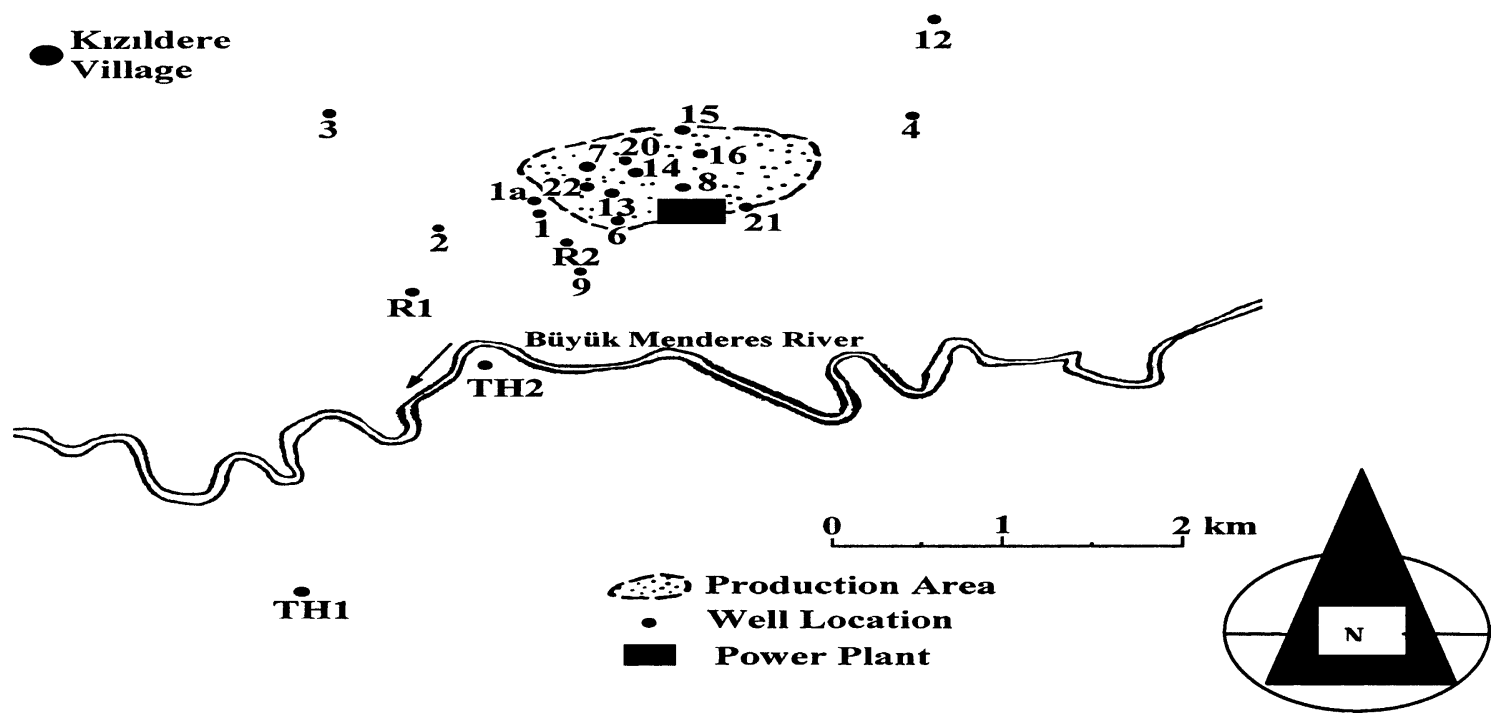

Fig. 3. Well locations of the Denizli-Kizildere geothermal field [18].

temperature, a depth of up to $1241 \mathrm{~m}$, a steam fraction of $10-12 \%$ and a higher permeability. So, the second reservoir was chosen as the production zone.

Fig. 3 illustrates the well locations of the DKGF [18]. The first well (the so-called KD-1) was drilled in 1968, and the temperature measured was $198^{\circ} \mathrm{C}$ at a depth of $540 \mathrm{~m}$. A total of 14 wells were drilled between 1968 and 1973, while the encountered temperatures were in the range of 170$212{ }^{\circ} \mathrm{C}$. A $0.5 \mathrm{MW}_{\mathrm{e}}$ pilot plant, which was fed from the KD-13 well, was installed in 1974 in the field. The electricity generated had met the demand of the villages around the field for a long time period. The MTA reported that 6 (KD-6, 7, 13, 14, 15, 16) out of 13 wells were suitable for electricity generation. The DKGPP was installed on February 14, 1984 with an installed capacity of $20.4 \mathrm{MW}_{\mathrm{e}}$. Then, 3 (KD-20, 21, 22) more production wells were drilled in two years, and the total number of production wells reached 9 [19]. In 1997, the R-1 well was drilled for injection purposes [20]. A liquid $\mathrm{CO}_{2}$ and dry ice production process with a capacity of 40,000 tons/yr was built adjacent to the field in 1986. The capacity of the process was increased to 120,000 tons/yr in 1999. Besides electricity and dry ice production, the resources of the field have also been used for greenhouse heating and space heating of offices and staff houses of the plant [21,22]. In Turkey, the first geothermal greenhouse heating system of 4.5 da was applied in the DKGF in 1985 [13].

Currently, the DKGPP employs 98 people including engineers, technicians and workers. The plant operates $8000 \mathrm{~h} / \mathrm{yr}$. The rest of the time is spent for maintenance such as cleaning the wells and overhaul. Electricity production cost was calculated as 1.75 cents/kWh in 2001 .

\section{Denizli-Kizildere geothermal field}

The main characteristics of the DKGF are given in Table 3 [19,23]. This field is a liquid dominated system with a steam fraction of $10-12 \%$. The steam field has an area of $550 \mathrm{~m} \times 650 \mathrm{~m}$, 
Table 3

Main characteristics of the Denizli-Kizildere geothermal field [19,23]

\begin{tabular}{lll}
\hline Description & Unit & Value \\
\hline Reservoir temperature & ${ }^{\circ} \mathrm{C}$ & $200-242$ \\
Wellhead steam fraction & $\%$ & $10-12$ \\
$\mathrm{CO}_{2}$ partial pressure $\left(P_{\mathrm{CO} 2}\right)$ & $\mathrm{MPa}$ & $3.0-5.0$ \\
Total dissolved solid (TDS) & $\mathrm{ppm}$ & $2500-3200$ \\
$\mathrm{NCG}$ content in steam (by wt.) & $\%$ & $10-21$ \\
$\mathrm{CO}_{2}$ content & $\%$ & $96-99$ \\
$\mathrm{H}_{2} \mathrm{~S}$ content & $\mathrm{ppm}$ & $100-200$ \\
\hline
\end{tabular}

Table 4

Gas analysis of some production and observation wells [23]

\begin{tabular}{|c|c|c|c|c|c|c|c|c|}
\hline Well no. & Date & $\begin{array}{l}\mathrm{H}_{2} \\
\text { (vol. \%) }\end{array}$ & $\begin{array}{l}\mathrm{O}_{2}-\mathrm{Ar} \\
(\mathrm{vol} \%)\end{array}$ & $\begin{array}{l}\mathrm{N}_{2} \\
\text { (vol. \%) }\end{array}$ & $\begin{array}{l}\mathrm{CH}_{4} \\
(\text { vol. } \%)\end{array}$ & $\begin{array}{l}\mathrm{CO}_{2} \\
(\text { vol. } \%)\end{array}$ & $\begin{array}{l}\mathrm{H}_{2} \mathrm{~S} \\
\text { (vol. } \% \text { ) }\end{array}$ & $\begin{array}{l}\mathrm{He} \\
(\mathrm{ppm})\end{array}$ \\
\hline KD 6 & May 9, 1988 & 0.3 & 0.1 & 1.8 & 0.3 & 97.5 & $<0.1$ & 5.4 \\
\hline KD 6 & June 15,1988 & $<0.1$ & 2.7 & 11.8 & $<0.1$ & 85.5 & $<0.1$ & 5.9 \\
\hline KD 6 & June 6,1988 & $<0.1$ & 2.1 & 8.5 & $<0.1$ & 89.4 & $<0.1$ & 8.2 \\
\hline $\operatorname{KD} 7^{\mathrm{a}}$ & May 8, 1988 & $<0.1$ & 0.1 & 0.5 & 0.1 & 89.3 & $<0.1$ & 15.6 \\
\hline $\mathrm{KD} 7^{\mathrm{a}}$ & June 29, 1988 & $<0.1$ & 2.4 & 8.8 & $<0.1$ & 88.8 & $<0.1$ & 7.7 \\
\hline KD 14 & June 30,1988 & $<0.1$ & 11.6 & 42.6 & $<0.1$ & 45.8 & 0.1 & 11.6 \\
\hline KD 16 & June 29,1988 & $<0.1$ & 2.4 & 9.2 & $<0.1$ & 88.4 & $<0.1$ & 10.9 \\
\hline KD 21 & June 23, 1988 & $<0.1$ & 1.6 & 3.6 & $<0.2$ & 94.8 & $<0.1$ & 14 \\
\hline KD 22 & May 8, 1988 & $<0.1$ & 0.6 & 1.7 & 0.1 & 97.5 & $<0.1$ & 15 \\
\hline
\end{tabular}

${ }^{\mathrm{a}}$ Observation well.

while the calculated reservoir area is $100 \mathrm{~km}^{2}$. The depth of the wells changes from 370 to $2261 \mathrm{~m}$. The reservoir temperature is between 200 and $242{ }^{\circ} \mathrm{C}$. The estimated capacity of the field is 200 $\mathrm{MW}_{\mathrm{e}}$. The most significant characteristic of the field is the high amount of non-condensable gases (2.5\% in the reservoir, $5 \%$ by volume of steam, $10-21 \%$ by weight of steam and average $13 \%$ by weight of steam at the turbine inlet) with a $\mathrm{CO}_{2}$ content of $96-99 \%, \mathrm{H}_{2} \mathrm{~S}$ content of $100-200 \mathrm{ppm}$ and $\mathrm{NH}_{3}$ content of $72 \mathrm{ppm}$. A gas analysis of some production and observation wells is given in Table 4 [23]. The specific steam consumption of the plant is $10.96 \mathrm{~kg} / \mathrm{kWh}$. The first law efficiency of the plant is determined to be $11.98 \%$.

A geothermal power plant can be divided into two sections, namely (a) steam field and (b) power generation unit including turbine house, cooling tower and related systems.

The major components of a steam field are:

(a) The wellbore,

(b) The wellhead with its valves,

(c) Separators if it is a liquid dominated system,

(d) A silencer,

(e) A ball check valve,

(f) A steam transmission system,

(g) A waste water system, and/or

(h) An injection system. 


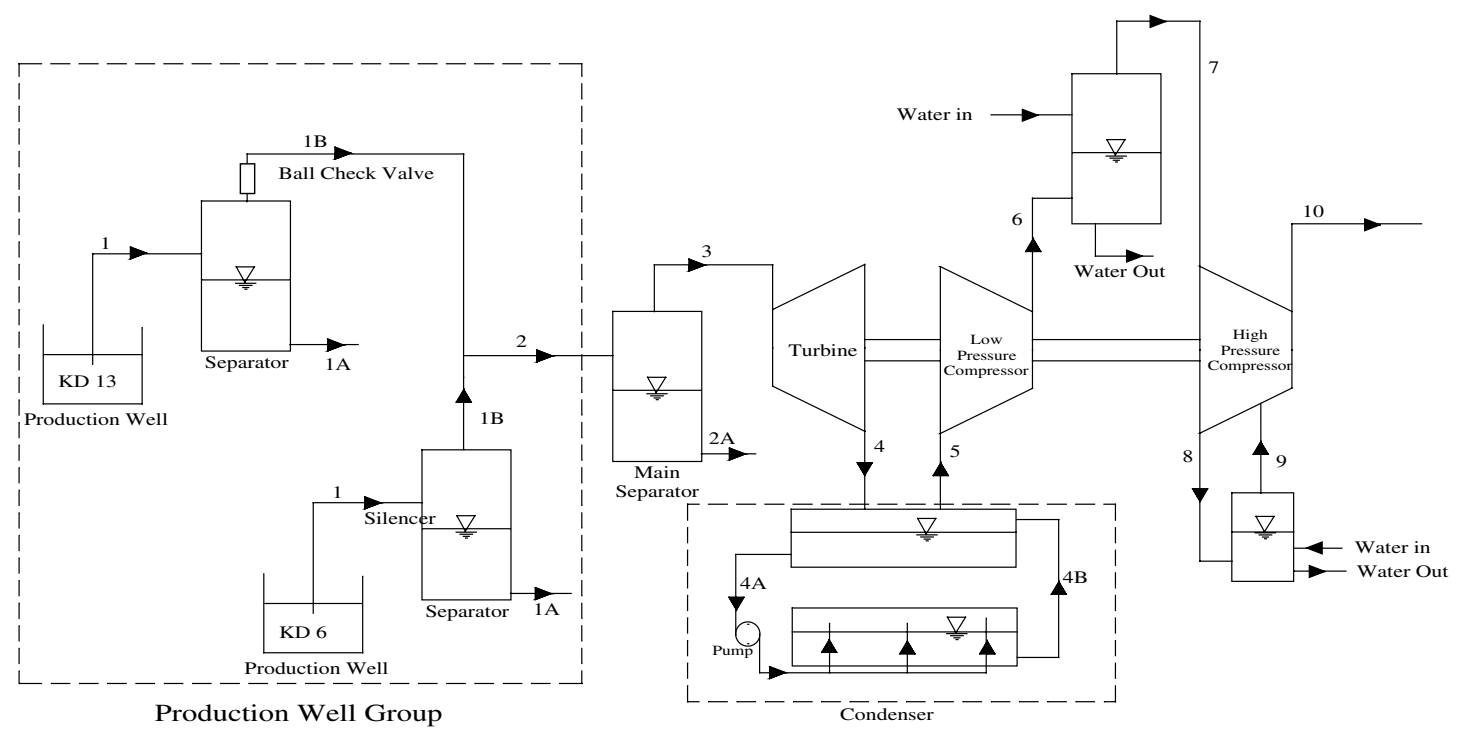

Fig. 4. Flow diagram of the Denizli-Kizildere geothermal power plant.

Fig. 4 shows the flow diagram of the DKGPP. In addition to the systems above, various pumps and fans, pipelines in various sizes, numerous valves of different designs and sizes, instruments to measure and monitor flow, temperature and pressure as well as controls of valves and pumps etc. are used in the field. The main components of the DKGF are described below.

(a) Wellbore. The well is the heart of the geothermal energy system. The enthalpy and mass flow of the produced fluid determine how the fluid will be used. The well is capped by the casing head flange to which is attached the rest of the wellhead equipment and wellhead valves. Wellbore characteristics change from field to field and, in some cases, from well to well.

(b) Wellhead. Geothermal fluid in reservoir conditions is compressed liquid at elevated temperatures and pressures. As the fluid flows through the well to the surface, it flashes into steam, and a wellhead quality of $10-12 \%$ is obtained.

The service valve is used to regulate the flow, while the master or shut off valve is used to close the well in or isolate the well for maintenance purposes. A bleed valve permits the removal of gas or to keep the well hot during shut in conditions, which avoids thermal cycling of the casing during alternating heating or cooling of the bore.

The wellhead characteristics of production and injection wells are given in Tables 5 and 6, respectively [24]. Wellhead pressures are kept as high as 1.1-1.45 MPa to prevent precipitation of $\mathrm{CaCO}_{3}$ in the wells.

(c) Separator. The geothermal fluid is sent to the separator, which is located at the wellhead of each well, to separate the steam and the liquid phases. The separators used in the DKGF are cyclone type separators with an outlet steam quality greater than $99 \%$ dry. The design and operating pressures of the separators are 1.7 and $0.377 \mathrm{MPa}$, respectively.

(d) Silencer. This is an atmospheric flasher with steam flashed vertically. With such a device, the noise is reduced from high to low frequency. The separated liquid is sent to a silencer, which 
Table 5

Production well data [24]

\begin{tabular}{|c|c|c|c|c|c|c|c|c|c|c|}
\hline Well no. & $\begin{array}{l}\text { Drilling } \\
\text { date }\end{array}$ & $\begin{array}{l}\text { Well- } \\
\text { head } \\
\text { temper- } \\
\text { ature } \\
\left({ }^{\circ} \mathrm{C}\right) \\
\end{array}$ & $\begin{array}{l}\text { Well- } \\
\text { head } \\
\text { pressure } \\
(\mathrm{MPa})\end{array}$ & Depth & $\begin{array}{l}\text { Total } \\
\text { flow } \\
\text { rate } \\
(\mathrm{kg} / \mathrm{s}) \\
\end{array}$ & $\begin{array}{l}\text { Separa- } \\
\text { tor pres- } \\
\text { sure } \\
(\mathrm{MPa})\end{array}$ & $\begin{array}{l}\text { Separa- } \\
\text { tor tem- } \\
\text { perature } \\
\left({ }^{\circ} \mathrm{C}\right)\end{array}$ & $\begin{array}{l}\text { Steam } \\
\text { flow } \\
\text { rate } \\
(\mathrm{kg} / \mathrm{s})\end{array}$ & $\begin{array}{l}\mathrm{CO}_{2} \\
\text { content } \\
\text { (by wt. } \\
\text { of steam) } \\
(\%)\end{array}$ & $\begin{array}{l}\text { Liquid } \\
\text { flow } \\
\text { rate } \\
(\mathrm{kg} / \mathrm{s})\end{array}$ \\
\hline KD-6 & 1970 & 194 & 1.356 & 851 & 23.32 & 0.367 & 147 & 2.80 & 20 & 20.52 \\
\hline KD-13 & 1971 & 198 & 1.387 & 760 & 26.31 & 0.377 & 145 & 3.16 & 17.4 & 23.15 \\
\hline KD-14 & 1970 & 210 & 1.356 & 597 & 29.13 & 0.387 & 148 & 3.50 & 10 & 25.63 \\
\hline KD-15 & 1971 & 208 & 1.387 & 510 & 31.59 & 0.377 & 147 & 3.79 & 17.5 & 27.80 \\
\hline KD-16 & 1975 & 212 & 1.427 & 666.5 & 45.45 & 0.387 & 148 & 5.45 & 12 & 40.00 \\
\hline KD-20 & 1986 & 204 & 1.448 & 810 & 30.48 & 0.377 & 147 & 3.66 & 13.7 & 26.82 \\
\hline KD-21 & 1985 & 205 & 1.101 & 898 & 32.03 & 0.387 & 147 & 3.84 & 10.6 & 28.19 \\
\hline KD-22 & 1985 & 204 & 1.386 & 888 & 28.24 & 0.367 & 147 & 3.39 & 14 & 24.85 \\
\hline R-1 & 1997 & 242 & 1.409 & 2261 & 44.44 & 0.369 & 148 & 5.33 & 21 & 39.10 \\
\hline
\end{tabular}

Table 6

Injection well data [24]

\begin{tabular}{llllcl}
\hline Well no. & $\begin{array}{l}\text { Wellhead } \\
\text { temperature }\left({ }^{\circ} \mathrm{C}\right)\end{array}$ & $\begin{array}{l}\text { Wellhead } \\
\text { pressure }(\mathrm{MPa})\end{array}$ & $\begin{array}{l}\text { Depth } \\
(\mathrm{m})\end{array}$ & $\begin{array}{l}\text { Total flow rate } \\
(\mathrm{kg} / \mathrm{s})\end{array}$ & Status \\
\hline TH-2 & 168 & N/A & 2001 & 11.67 & $\begin{array}{l}\text { Abandoned } \\
\text { Converted to } \\
\text { R-1 }\end{array}$ \\
242 & 1.962 & 2261 & 103.05 & $\begin{array}{l}\text { Inoduction well } \\
\text { R-2 }\end{array}$ \\
\hline
\end{tabular}

discharges the wastewater over a measuring weir to determine the well output characteristics before its disposal to the wastewater channel. From May to August 2002, two wells were connected to the injection well for injection trials. So, the silencers are only used to by-pass the well output when it is necessary.

(e) Ball check valve. The steam from the separator is first sent to a safety unit, which employs a ball check valve to prevent water entrance to the steam line. If water moves with the steam, the ball ascends and seals the flow.

(f) Steam transmission system. The wells are connected individually through a wellhead separator via a steam branch line to the main steam transmission line with a length of $1171 \mathrm{~m}$ to the power plant. The pipeline is insulated to reduce heat loss and to conserve the enthalpy of the fluid. Condensation traps achieve control of the condensate in the bottom of the pipe, which is caused by heat loss. This also ensures adequate scrubbing, particularly of the salts, and a clean fluid is presented to the turbine.

(g) Waste water system. Only $10-12 \%$ of the brine extracted from the ground turns into steam after the separation process, while the remainder $(88-90 \%)$ has been disposed to the Menderes river through a $1.8-\mathrm{km}$ long channel at an average temperature of $147^{\circ} \mathrm{C}$ and a total flow rate of $277.7 \mathrm{~kg} / \mathrm{s}$ since 1984 . 
(h) Injection system. The commonly acceptable method of dealing with wastewater is to inject it back into a part of the reservoir.

The first pilot injection test in the DKGF was conducted in 1976 and lasted for 29 weeks. The water produced from well KD-15 was injected into well KD-1A at an average rate of $23.61 \mathrm{~kg} / \mathrm{s}$. The injected water temperature varied from 70 to $80{ }^{\circ} \mathrm{C}$. Well $\mathrm{KD}-1$, which is $68 \mathrm{~m}$ away from KD-1A, was chosen as an observation well. The cooling effect was encountered at the observation well. A heat flow model describing the non-isothermal fluid flow in naturally fractured reservoirs is applied, and the temperature behavior in the observation well is predicted.

The second test lasted for 45 days in 1995. The water produced from KD-20 was injected into well KD-7 by gravity. The wellhead injection temperature was $100{ }^{\circ} \mathrm{C}$. The decline in injectivity is related to the possible plugging by scale deposition in the injector. The producer well KD-20 also served as an observation well for monitoring the produced water temperature and chloride $\left(\mathrm{Cl}^{-}\right)$ concentration. Some change in the chloride content but no change in the temperature of the produced water was observed. Because of the limitations in technical conveniences at that time, the actual reasons for the plugging difficulty have never been revealed [25].

After those trials, an injection well (TH-2) was designed to drill on the other side of the Menderes river in the Tekkehamam field, which is $3 \mathrm{~km}$ away from the DKGF. The injectivity of the well was poor, and hence, it was abandoned.

According to the injection program of the MTA, another injection well (R-1) was drilled in the DKGF boundary in 1997. R-1 indicated that a third reservoir with a temperature range of 235$245^{\circ} \mathrm{C}$ exists in the DKGF. Taking into account the completion test results, it may be concluded that the well has a high productivity with figures of $103.05 \mathrm{~kg} / \mathrm{s}$ and $6 \mathrm{MW}_{\mathrm{e}}$ with the highest temperature in the field having a bottomhole temperature of $242{ }^{\circ} \mathrm{C}$ at $2261 \mathrm{~m}$. Based on the data obtained, the R-1 well was converted to a production well in 2001, and the production of the plant increased by $6.5 \%$. The production rate of the plant between 1984 and 2001 is illustrated in Fig. 5 [24,26].

Following the R-1 well drilling, the MTA conducted some injection trials at abandoned wells in the field in 1998-99, but a drastic temperature drop was observed in the production wells. In 2000, a new injection well (R-2) was initiated to drill and was completed in 2001 with a depth of $1371 \mathrm{~m}$.

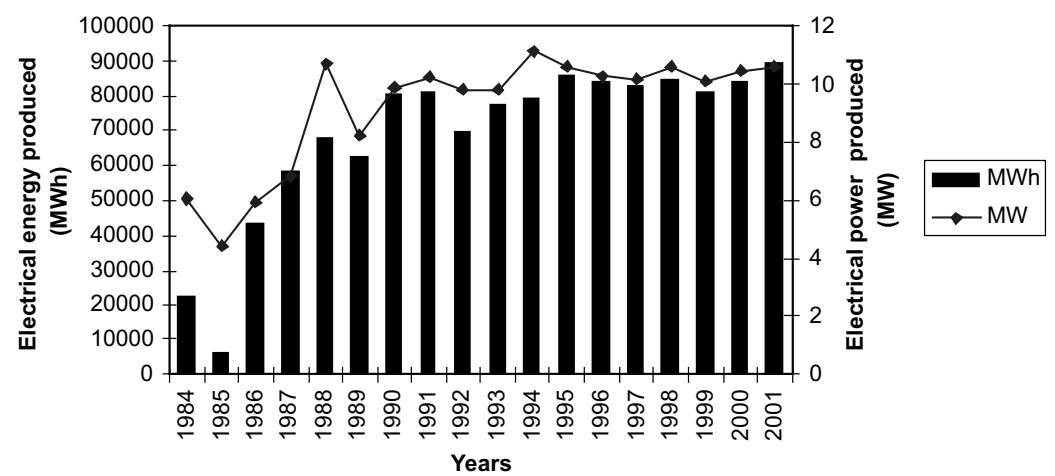

Fig. 5. Electricity generation of the Denizli-Kizildere geothermal power plant between 1984 and 2001 [24,26]. 
Injection trials in R-2 have been conducted for 3 months from May to August 2002. Separated liquid from 2 production wells at a flow rate of $55.55 \mathrm{~kg} / \mathrm{s}$ and a temperature of $125-135{ }^{\circ} \mathrm{C}$ were injected by gravity. The results of the trials have not been reported yet.

Based upon the injection strategy recommended by Serpen and Satman [20], the Kizildere system would produce from the deeper and hotter third reservoir and inject to the shallow reservoir. Since the third reservoir produces more steam than the second reservoir, which is used as a production zone, the amount of water to inject will decrease approximately by half.

\section{Denizli-Kizildere geothermal power plant}

The DKGPP is a single flash system with a condensing low pressure double flow turbine. The plant operates with a $90 \%$ load factor. The main characteristics of the DKGPP are given in Table $7[19,24,27]$, while the major components of the power generation unit are as follows:

(a) Scrubber (main moisture separator),

(b) Turbine-generator unit,

(c) Condenser,

(d) Gas removal system,

(e) Cooling tower,

(f) Auxiliary equipment (parasitic loads).

Table 7

Main characteristics of the Denizli-Kizildere geothermal power plant $[19,24,27]$

\begin{tabular}{lll}
\hline Description & Unit & Value \\
\hline $\begin{array}{l}\text { Number of production wells } \\
\text { Optimum wellhead pressure }\end{array}$ & $\mathrm{MPa}$ & 9 \\
& & 1.6 \\
Wellhead operation pressure & $\mathrm{MPa}$ & $1.28-1.58$ \\
Wellhead temperature & ${ }^{\circ} \mathrm{C}$ & $180-190$ \\
Total flow rate & $\mathrm{kg} / \mathrm{s}$ & 320.83 \\
Separator pressure & $\mathrm{MPa}$ & $0.367-0.387$ \\
Separator temperature & ${ }^{\circ} \mathrm{C}$ & $145-148$ \\
Steam flow rate & $\mathrm{kg} / \mathrm{s}$ & $25-38.88$ (av. 33.34) \\
Steam pressure at safety valve & $\mathrm{MPa}$ & 0.35 \\
Steam temperature at safety valve & ${ }^{\circ} \mathrm{C}$ & 147.2 \\
Turbine pressure & $\mathrm{MPa}$ & 0.378 \\
Turbine temperature & ${ }^{\circ} \mathrm{C}$ & 147 \\
Back pressure at turbine exhaust & $\mathrm{MPa}$ & 0.01 \\
Steam wetness at turbine exhaust & $\%$ & 9.5 \\
NCG flow rate & $\mathrm{kg} / \mathrm{s}$ & 6.1345 \\
Capacity & $\mathrm{MW}$ & Installed \\
& & Gross \\
Compressor consumption & & Net \\
& $\mathrm{MW}$ & 2.38 \\
& & $(12 \%$ of installed capacity, $17 \%$ of gross capacity) \\
\hline
\end{tabular}


Table 8

Main characteristics of turbine-generator unit [19]

\begin{tabular}{lll}
\hline Description & Unit & Value \\
\hline Turbine inlet temperature & ${ }^{\circ} \mathrm{C}$ & 147 \\
Turbine inlet pressure & $\mathrm{MPa}$ & 0.378 \\
Turbine inlet enthalpy & $\mathrm{kJ} / \mathrm{kg}$ & 2742.35 \\
Steam flow rate (average) & $\mathrm{kg} / \mathrm{s}$ & 33.34 \\
Steam flow rate (at maximum output) & $\mathrm{kg} / \mathrm{s}$ & 42.42 \\
Turbine exit temperature & ${ }^{\circ} \mathrm{C}$ & $42-44$ \\
Turbine exit pressure & $\mathrm{MPa}$ & 0.01019 \\
Turbine exit enthalpy & $\mathrm{kJ} / \mathrm{kg}$ & 2357.6 \\
Water enthalpy at condenser pressure & $\mathrm{kJ} / \mathrm{kg}$ & 190 \\
Turbine rotor speed & $\mathrm{rpm}$ & 3000 \\
Rated output & $\mathrm{kW}$ & 17,800 \\
Maximum output & $\mathrm{kW}$ & 17,800 \\
Compressor power & $\mathrm{kW}$ & 2380 \\
Thermal efficiency & $\%$ & 11.98 \\
Turbine-generator efficiency & $\%$ & 71.2 \\
\hline
\end{tabular}

(a) Scrubber. Outside of the turbine house, the steam enters a scrubber to remove the impurities and condensate. At the exit of the scrubber, the steam goes to a demister to remove the moisture and splits into two branches that are sent to the double flow turbine.

(b) Turbine-generator unit. The double flow turbine used in the DKGPP consists of two turbines on the same shaft with steam flowing in opposite directions. It is preferred because of its lower capital cost and the balance on the thrust loads. The turbine has seven reaction stages on both sides. The main characteristics of the turbine-generator system of the DKGPP are illustrated in Table 8 [19]. The pressure and temperature of the turbine are $0.378 \mathrm{MPa}$ and $147^{\circ} \mathrm{C}$, respectively. The total steam flow rate, including NCG's, enters the turbine at a flow rate of $33.34 \mathrm{~kg} / \mathrm{s}$, expands to $0.01019 \mathrm{MPa}$ and flows to the condenser. To protect the leading edge of the last blades of the turbine from erosion and corrosion by water droplets, stellite erosion shields coat the blades, and to remove the condensate, drain channels are added. The turbine is protected by safety discs against excess pressure differentiation during drainage. The turbine-generator efficiency is determined to be $71.2 \%$.

(c) Condenser. A direct contact condenser with barometric leg, situated under the turbine, is used in the DKGPP. Direct contact condensers are the least affected condensers from harmful physical and chemical impacts of the fluid. The heat transfer coefficient is also higher than with surface type condensers.

The condenser consists of two sections: the first one is a co-current horizontal section where the cooling water contacts steam, while the second one is a vertical barometric leg where NCG's and a small fraction of uncondensed steam are accumulated and the condensate flows down to be pumped to the cooling tower. The cooling water $(2375 \mathrm{~kg} / \mathrm{s})$ is sucked from the cooling tower by vacuum in the condenser at $29^{\circ} \mathrm{C}$ temperature and flow rate and then sprayed over the steam by nozzles. Two centrifugal pumps are used to pump the condensate with a temperature of $36.6{ }^{\circ} \mathrm{C}$. The condenser is manufactured of stainless steel for corrosion protection. To prevent plugging of the nozzles, the nozzle diameters are kept as wide as $50 \mathrm{~mm}$. The condenser-turbine coupling is made of stainless steel to absorb the vibration and thermal expansions. 
(d) Gas removal system. In the DKGPP, NCG's are extracted from the condenser by a compressor and passed to the dry ice production plant, which produces dry ice and liquid $\mathrm{CO}_{2}$ at a rate of 120,000 tons/yr. The capacity of the gas extraction system is $2.38 \mathrm{MW}_{\mathrm{e}}(17 \%$ of the gross capacity) due to a high NCG content.

The general configuration consists of a two body compressor with two inter-coolers. The first unit rotor (LP) is directly coupled to the turbo-generator and, hence, rotates at $3000 \mathrm{rpm}$. The second unit (HP) is driven from the first, via a speed increasing gear and rotates at $3900 \mathrm{rpm}$. The characteristics of the centrifugal compressor in the plant are given in Table 9 [24].

(e) Cooling tower. A wet mechanical draft cooling tower is used to cool the condensate, which is used in the condenser as cooling water. The cooling tower employs four motor driven fans, each consuming $110 \mathrm{kWh}$. The fans are located at a height of $11.5 \mathrm{~m}$. The condensate is pumped to a height of $8.5 \mathrm{~m}$, distributed through headers and falls to the basin. Each cell is a separate unit with its own fan and louvered openings on only two sides. The cells are arranged side by side in a long row. The cell dimension is $15 \mathrm{~m} \times 15 \mathrm{~m}$. The width, length and height of the cooling tower are 15 , 60 and $15 \mathrm{~m}$, respectively. Airflow is counter-current, and the construction material is concrete. The condensate at $36.6{ }^{\circ} \mathrm{C}$ is cooled to $29^{\circ} \mathrm{C}$ by evaporation. The feed water to substitute for the evaporated water $(1.7 \%)$ and leakage losses comes from the Menderes river.

(f) Auxiliary equipment. The parasitic load in the plant accounts for about $20 \%$ of its gross capacity. The highest portion of the parasitic load is the compressor consumption, which

Table 9

Main characteristics of gas compressors in the Denizli-Kizildere geothermal power plant [24]

\begin{tabular}{lll}
\hline Description & $\mathrm{Unit}$ & Value \\
\hline Gas content & $\%$ & $99.9 \mathrm{CO}_{2}, 0.1 \mathrm{H}_{2} \mathrm{~S}$ \\
Gas flow rate & $\mathrm{kg} / \mathrm{s}$ & 6.44 \\
$\quad$ & $\mathrm{~kg} / \mathrm{s}$ & \\
$\quad$ Steam flow rate & & 2.47 \\
$\quad$ (LP suction) & $\mathrm{kg} / \mathrm{s}$ & \\
Total gas flow rate (suction) & $\mathrm{m}^{3} / \mathrm{h}$ & 8.91 \\
Compressor suction capacity & ${ }^{\circ} \mathrm{C}$ & 293,500 \\
Cooling water inlet temperature & $\mathrm{m} / \mathrm{h}$ & 29 \\
Cooling water flow rate & $\mathrm{rpm}$ & 900 \\
LP compressor rotor speed & ${ }^{\circ} \mathrm{C}$ & 3000 \\
LP suction temperature & $\mathrm{MPa}$ & 53 \\
LP suction pressure & ${ }^{\circ} \mathrm{C}$ & 0.08 \\
LP discharge temperature & $\mathrm{MPa}$ & $50-52$ \\
LP discharge pressure & $\mathrm{rpm}$ & 0.1013 \\
HP compressor rotor speed & ${ }^{\circ} \mathrm{C}$ & 3900 \\
HP suction temperature & $\mathrm{MPa}$ & $50-52$ \\
HP suction pressure & ${ }^{\circ} \mathrm{C}$ & 0.093 \\
HP discharge temperature & $\mathrm{MPa}$ & $35-40$ \\
HP discharge pressure & $\mathrm{rpm}$ & 0.34 \\
Critical speed LP rotor & $\mathrm{rpm}$ & 1986 \\
$\quad$ (calculated) HP rotor & & 1730 \\
No. of bodies & & 2 \\
No. of inter coolers & $(\mathrm{kW})$ & 2 \\
Power & & 2380 \\
\hline
\end{tabular}


Table 10

Power consumption of auxiliary equipment in the Denizli-Kizildere geothermal power plant [19]

\begin{tabular}{lclc}
\hline Equipment & Unit power $\left(\mathrm{kW}_{\mathrm{e}}\right)$ & No. of units & Total power $\left(\mathrm{kW}_{\mathrm{e}}\right)$ \\
\hline Compressor & 2380.0 & 1 & 2380 \\
Main lubrication pump & 37.3 & 1 & 37.3 \\
Drill collar pumps & 0.185 & 2 & 0.37 \\
Emergency bearing lubrication pump & 37.3 & 1 & 37.3 \\
Demister & 2.24 & 1 & 2.24 \\
Cooling tower fan motor & 37.285 & 4 & 149.14 \\
Water pump (domestic use and cooling water) & 37.0 & 2 & 74.0 \\
Sand filters water pump & 7.5 & 2 & 15.0 \\
Sand filters back wash pump & 3.0 & 2 & 6.0 \\
Dosage pump & 0.25 & 3 & 0.75 \\
Chlorinated water pump & 37.0 & 2 & 74.0 \\
Service air compressor & 37.0 & 2 & 74.0 \\
Air drier & 1.5 & 1 & 1.5 \\
Grand total & & & 2851.6 \\
\hline
\end{tabular}

constitutes $83 \%$ of the total parasitic load and $17 \%$ of gross capacity. The auxiliary equipment consumption is given in Table 10 [19].

\section{Conclusions}

Geothermal utilization is commonly divided into two categories, namely electric energy production and direct (or non-electric) uses. This study focused on the former, namely power generation. The main conclusions derived from the present study may be summarized as follows:

(a) In Turkey, there are nine geothermal fields suitable for generating electricity.

(b) Based on the values for wells drilled, Turkey's geothermal power production potential is estimated to be $764.81 \mathrm{MW}_{\mathrm{e}}$.

(c) The only operating geothermal power plant of Turkey is the Denizli-Kizildere geothermal power plant with an installed capacity of $20.4 \mathrm{MW}_{\mathrm{e}}$, while the total capacity of the field is estimated to be $200 \mathrm{MW}_{\mathrm{e}}$.

(d) There is not any 'geothermal law in Turkey' as yet. There is, however, a 'draft geothermal law'. It is expected that geothermal energy development will significantly increase in the country if this law becomes effective.

(e) The first law efficiency of the DKGPP is determined to be $11.98 \%$. By comparison, the efficiency of generation of electricity from geothermal steam is generally in the range of 10 to $17 \%[4]$.

(f) Only $10-12 \%$ of the brine extracted from the ground turns into steam after the separation process, while the remainder $(88-90 \%)$ has been discharged to the Menderes river at an average temperature of $147^{\circ} \mathrm{C}$ and a total flow rate of $277.7 \mathrm{~kg} / \mathrm{s}$ since 1984 . Therefore, the plant efficiency may be improved by using the brine instead of discharging it to the Menderes river. In this regard, the existing plant may be combined with a binary geothermal power plant, 
which is especially suitable for operating temperatures at around $150{ }^{\circ} \mathrm{C}$. The use of the brine for heating purposes also consists of another alternative.

\section{Acknowledgements}

The authors are grateful for the support provided for the present work by the General Directorate of the Denizli-Kizildere geothermal power plant, General Directorate of Mineral Research and Exploration of Turkey (MTA) and Turkish Electricity Generation and Transmission Corporation (TEAS).

\section{References}

[1] Anonymous. Declaration of the World Geothermal Congress 2000. 28 May-10 June, Kyushu and Tohoku, Japan; 2000 (in English and Japanese).

[2] ASHRAE, American Society of Heating, Refrigerating, and air-conditioning engineers, Inc. Handbook of applications, Atlanta, GA, 2000 (Chapter 29).

[3] Kanoglu M, Cengel YA. Economic evaluation of geothermal power generation, heating, and cooling. Energy 1999;24:501-9.

[4] Barbier E. Geothermal energy technology and current status: an overview. Renew Sust Energy Rev 2002;6:3-65.

[5] Huttrer GW. The status of world geothermal power generation 1995-2000. In: CD-Proceedings of World Geothermal Congress 2000, Kyushu-Tohuko, Japan, May 28-June 10; 2000. p. 23-37.

[6] Huttrer GW. The status of world geothermal power generation 1995-2000. Geothermics 2001;30:1-27.

[7] Lund JW. Direct heat utilization of geothermal resources. Renew Energy 1997;10(2/3):403-8.

[8] Bidini G, Desideri U, Di Maria F, Baldacci A, Papale R, Sabetelli F. Optimization of an integrated gas turbinegeothermal power plant. Energy Convers Mgmt 1998;39(16-18):1945-56.

[9] Batik H, Kocak A, Akkus I, Simsek S, Mertoglu O, Bakir N. Geothermal energy utilization development in Turkey_present geothermal situation and projections. In: CD-Proceedings of World Geothermal Congress 2000, Kyushu-Tohuko, Japan, May 28-June 10; 2000. p. 85-91.

[10] Mertoglu O. Geothermal district heating experience in Turkey. Geo-heat Center Bull 2001;22(2):14-8.

[11] Kocak A. One of the renewable energy sources applied in Turkey: geothermal energy. In: Proceedings of Turkish Second Energy Symposium, Chamber of Electrical Engineers, Ankara, Turkey, 22-24 November 1999. p. 119-26 (in Turkish).

[12] Akkus I, Aydogdu O, Sarp S. Place of geothermal energy in meeting the energy requirement of our country. In: Proceedings of Fourth Clean Energy Symposium, 16-18 October, Istanbul, Turkey; 2002. p. 619-28 (in Turkish).

[13] Gunerhan G, Kocar G, Hepbasli A. Geothermal energy utilization in Turkey. Int J Energy Res 2001;25(9):769-84.

[14] Hepbasli A, Gunerhan H. A study on the utilization of geothermal heat pumps in Turkey. In: CD-Proceedings of World Geothermal Congress 2000, Kyushu-Tohuko, Japan, May 28-June 10; 2000. p. 3433-8.

[15] Mertoglu O. Applications of geothermal energy in Turkey and its development. In: Proceedings of the Geothermal Energy in Local Governments and Geotechnical Applications Symposium, Ankara, Turkey, 20-22 November 2000. p. 1-7 (in Turkish).

[16] GRC, Geothermal Resources Council. News briefs. Geothermal Bull 1998;27(1):5.

[17] Hepbasli A, Ozalp N. Present status of cogeneration applications in Turkey. Energy Sources 2002;24:169-77.

[18] Giese LB. Geotechnische und umweltgeologische Aspecte bei der Foerderung und Reinjection von Thermalfluiden zur Nutzung geothermischer Energie am Beispiel des geothermalfeldes Kizildere und des umfeldes, W-Anatolien/ Turkei, Ph.D. Thesis, Free University Berlin Fac. of Geosciences; 1997, 201 p (in German).

[19] Sarikurt H. Report on the Kizildere Geothermal Power Plant, 1983 (in Turkish). 
[20] Serpen U, Satman A. Reassessment of the Kizildere geothermal reservoir. In: CD-Proceedings of World Geothermal Congress, Kyushu-Tohuku, Japan, May 28-June 10; 2000. p. 2869-74.

[21] Simsek S. Present status and future development of the Denizli-Kizildere geothermal field of Turkey. In: International Symposium on Geothermal Energy, Geothermal Resources Council, Int. Vol.; 1985; 203-14.

[22] Simsek S, Demirel, Z. Geothermal energy reserves in Turkey. In: K, Popovski, AN, Rodrigues (Eds.), Proceedings of the International Workshop, Heating Greenhouses with Geothermal Energy, International Geothermal Days, Azores, Portugal, 1998. p. 355-66.

[23] MTA, General Directorate of Mineral Research and Exploration of Turkey. Steam field and power plant data. Personal communication, 1996 (in Turkish).

[24] TEAS, Turkish Electricity Generation and Transmission Corporation. Personal communications on the DenizliKizildere geothermal power plant, 2002 (in Turkish).

[25] Satman A, Serpen U, Mihcakan M. Assessment of reinjection trials in Kizildere geothermal field. In: CDProceedings of World Geothermal Congress, Kyushu-Tohuku, Japan, May 28-June 10; 2000. p. 1695-1700.

[26] SPO, State Planning Organization. Eighth Five-Year Development Plan. Report of Geothermal Energy Special Commission. SPO (DPT), Ankara, Turkey, 2001 (in Turkish).

[27] Gunerhan GG. Theoretical and experimental investigations on condensation/boiling modeled heat exchangers (reboilers) designed for removal of noncondensable gases from geothermal steam. Ph.D. Thesis, Graduate School of Natural and Applied Science, Branch of Solar Energy Science, Ege University, Bornova, Izmir, Turkey, 2000 (in Turkish). 